\title{
FeAlを結合相とする超硬合金のパルス通電焼結による作製
}

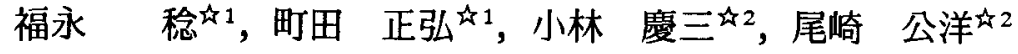

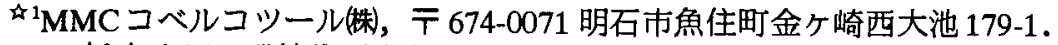 \\ 的2名古屋工業技術研究所， $\bar{T} 462-8510$ 名古屋市北区平出町 1-1。
}

\section{Preparation of Cemented Carbide with FeAl Binder Phase by Pulsed Current Sintering Process}

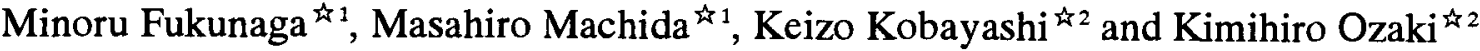 \\ 1 MMC Kobelco Tool Co., Ltd., 179-1 Nishioike Kanagasaki Uozumi-cho, Akashi 674-0071. \\ ${ }^{2}$ National Industrial Research Institute of Nagoya, 1-1 Hirate-cho Kita-ku, Nagoya 462-8510.
}

Received January 11, 2000

\begin{abstract}
SYNOPSIS
The microstructure, mechanical properties and high temperature oxidation resistance of $\mathrm{WC}-10 \mathrm{mass} \%\left(\mathrm{Fe}_{65} \mathrm{Al}_{35}\right)$ and $\mathrm{WC}-10$ mass\%( $\left.\mathrm{Fe}_{625} \mathrm{Al}_{32.5} \mathrm{~B}_{5}\right)$ alloys were investigated. $\mathrm{Fe}_{65} \mathrm{Al}_{35}$ or $\mathrm{Fe}_{62.5} \mathrm{Al}_{32.5} \mathrm{~B}_{5}$ were synthesized by mechanical alloying (MA) for $540 \mathrm{ks}$ of $\mathrm{Fe}$ and $\mathrm{Al}$ powders, or $\mathrm{Fe}, \mathrm{Al}$ and $\mathrm{B}$ powders. The obtained MA powders and WC powder were mixed with organic solvent in the planetary ball mill. The mixtures were consolidated by pulsed current sintering process.

WC-10mass\%(Fe $\left.{ }_{625} \mathrm{Al}_{32.5} \mathrm{~B}_{5}\right)$ alloy has higher density and higher hardness than WC-10mass\% $\left(\mathrm{Fe}_{65} \mathrm{Al}_{35}\right)$ alloy. WC-10mass \% $\left(\mathrm{Fe}_{62.5} \mathrm{Al}_{32.5} \mathrm{~B}_{5}\right)$ alloy containing 0.37 mass \% of oxygen has transverse-rupture strength of $0.78 \mathrm{GPa}$, which is higher than twice of that of alloys containing 3.4 mass $\%$ of oxygen.

The oxidization of the cemented carbides with $\mathrm{FeAl}$ binder phase in the air starts at higher temperature than that of conventional WC-Co alloy. Especially, WC-10mass\% $\left(\mathrm{Fe}_{62.5} \mathrm{Al}_{32.5} \mathrm{~B}_{5}\right)$ alloy has excellent oxidization resistance at $1041 \mathrm{~K}$.

\section{KEY WORDS}

cemented carbide, WC-Fe-Al alloy, WC-Fe-Al-B alloy, pulsed current sintering, oxidation resistance
\end{abstract}

\section{1 緒 言}

筆者らは Fe-Al 系の金属間化合物の耐酸化性, 耐食性の良 さに注目し,Fe-Al金属間化合物を結合相とする超硬合金につ いて作製を試み，優れた硬さと耐酸化性を示す超硬合金が作

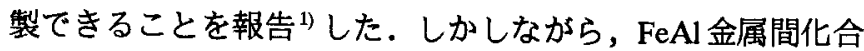
物では $\mathrm{Al}$ 量比率が高い方が耐酸化性，耐食性が優れているの に対してこのような合金を結合相とする超硬合金では $\mathrm{Al}$ 量 比率が增すにつれて焼結性が悪くなり，WC-6.7mass\% Fe3.3mass\%Al合金はWC-8.6mass\%Fe-1.4mass\%Al合金よりもか えって耐酸化性が悪化する結果 ${ }^{2}$ となった.そこで, 本研究で はあらかじめメカニカルアロイング法によって作製した合金 を結合相として用いることにより, 前報より $\mathrm{Al}$ 量比率の高い 超硬合金の作製を検討した．また，メカニカルアロイング法 で合成された粉末とWC粉末との湿合粉末をパルス通電焼結 法により固化成形することも試みた．さらに，結合相に B 添加した場合の影響についても検討を行った。

\section{2 試料調整及び実験方法}

$\mathrm{Fe}$ 粉末 $(99.8 \mathrm{mass} \% \mathrm{Fe}$ ，水アトマイズ鉄粉，神戸製鋼所製 300NH)，Al 粉末 (99.5mass\%Al) および B 粉末 (99mass\%B，ア モルファス状粉末)を $\mathrm{Fe}-35 \mathrm{at} \% \mathrm{Al}$ (以下, $\mathrm{Fe}_{65} \mathrm{Al}_{35}$ と記す)また は Fe-32.5at\%Al-at\%5B (以下， $\mathrm{Fe}_{62.5} \mathrm{Al}_{32.5} \mathrm{~B}_{5}$ と記す) になる様 に秤量し，遊星型ボールミル(伊藤製作所製 LA-PO.4)により 高純度アルゴンガス中で $540 \mathrm{ks}$ 間メカニカルアロイング (以 下，MAと記す) 処理を行った.MAにはクロム鋼 $(\mathrm{Fe}-$ $11 \mathrm{mass} \% \mathrm{Cr})$ 製の容器 $(500 \mathrm{ml})$ に $10 \mathrm{~mm}$ 径のクロム鋼製のボー ルを 100 球充填して，処理を行った，処理重量はボール重量 のおよそ5\%とした.なお, 遊星型ボールミルの自転および公 転速度は 170r.p.m.としている。

MAで得られた粉末が結合相量として 10mass\% (以下, mass\%は単に\%と記す)なるよう, WC粉末 (FSSS 径 $0.6 \mu \mathrm{m}$ ) と混合し, Fe-Al合金を MA処理した場合と同じ遊星型ボール ミルを用いて，有機溶媒中で 3.6ks 間湿式混合を行った.一部 
の粉末については後述するように混合粉末に $0.5 \%$ あいは 1.0\%の黒鉛粉末を添加した. 得られた混合粉末は黒鉛型を用 いてパルス通電焼結を行った. 焼結条件は加圧力を $33 \mathrm{MPa}$ と し，焼結温度は型におよそ $3 \mathrm{~mm}$ 挿入した熱電対が $1423 \sim$ $1473 \mathrm{~K}$ になるようにした. なお, 保持時間は 300 s間とした. 得 られた試料は, JIS B4053の試験片形状に研削加工し, 密度測 定, 硬さ測定, 抗折試験, 光学顕微鏡による組織観察, 合金 の相同定のためにX線回折, SEM/EDXによる分析, 酸化試験 などを行った.

\section{3 実験結果及ひ考察}

\subsection{WC-10\% $\left(\mathrm{Fe}_{65} \mathrm{Al}_{35}\right)$ 系合金の焼結評価}

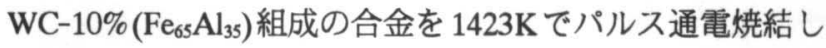
た組織を Fig.1 に示す．本合金の硬さは HRA90.0，密度は $12.3 \mathrm{~g} / \mathrm{cm}^{3}$ であり, その抗折力は $0.39 \mathrm{GPa}$ であった. 抗折力は Coを結合相とした一般の超硬合金に比べると, 非常に低い值 である. その原因として焼結体の密度が低いことが考えられ る. そこで, Fig.1(a)の低倍率における組織写真をよく観察し てみると, 黒色に見える部分がポアであることがわかった. このポアの存在により抗折力の低下を招いているとも考られ るが, 得られた超硬合金には本来存在する WC粒子と結合相 以外に第3の相が存在することがわかる. 特に, Fig.1(b)の高 倍率の組織写真において矢印で示される第 3 の相はポアに比 べて, かなり大きいものであり, ポアよりも抗折力の低下に 関与しているものと考えられる. さらに, 得られた超硬合金 の炭素量について分析したところ, 5.40\% (WC が化学量論組 成であり, 結合相に固溶炭素がなく, 遊離炭素も存在しない と仮定すると, 本合金の炭素量は理論上 $5.52 \%$ になる ) と低 く, 超硬合金で問題となる $\eta$ 相 $\left(\mathrm{M}_{6} \mathrm{C}\right.$ 型炭化物 $)$ が生成してい る可能性も示唆された.

そこで, MA 粉末と WC 粉末の混合粉末に, 合金の総重量 に対して $0.5 \%$ あるいは $1.0 \%$ の炭素粉末を添加して同じ焼結 条件にて固化成形を行った.これらの合金の組織をFig.2に示 す.これら合金の硬さはそれぞれ HRA90.6および HRA88.6, 密度は $12.9 \mathrm{~g} / \mathrm{cm}^{3}$ および $12.4 \mathrm{~g} / \mathrm{cm}^{3}$ を示した. また，抗折力は
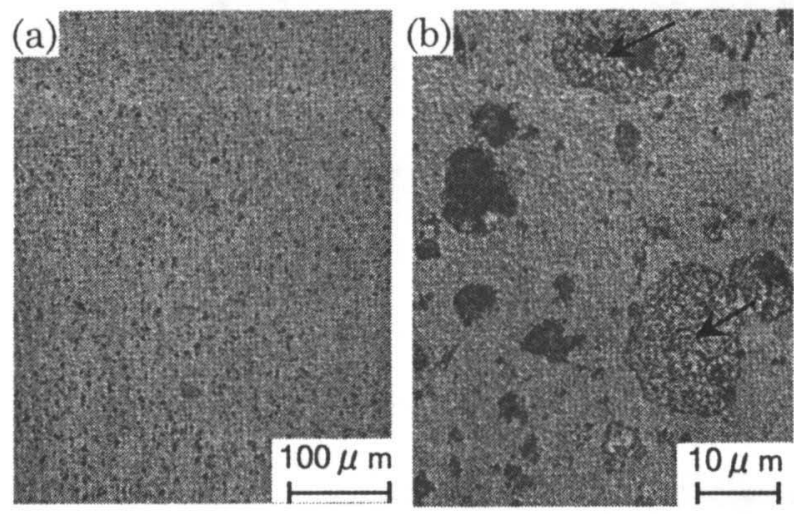

Fig.1 Microstructure of WC-10mass\% $\left(\mathrm{Fe}_{65} \mathrm{Al}_{35}\right)$ alloy pulsed current sintered at $1423 \mathrm{~K}$ under $33 \mathrm{MPa}$.

(a) low magnification (b) high magnification
それぞれ0.37GPaおよび0.41GPaであった. 炭素を添加したこ とによる組織の大きな変化は観察されなかった. 添加した炭 素量が $0.5 \%$ の試料では若干ながら密度および硬さの向上が認 められた．しかし，抗折力は炭素を添加しなかった合金とほ とんど差が生じていない. なお, $0.5 \%$ および $1.0 \%$ の炭素を添 加した合金では，合金炭素量はそれぞれ 5.81\% および $6.21 \%$ となっており,いずれも理論値である $5.52 \%$ を越えていた.炭 素を添加しなかった合金と1.0\%の炭素を添加した合金につい てその構成相の違いを調べるために, $\mathrm{X}$ 線回折を行った. 得 られた回折パターンをFig.3に示す. 炭素を添加していない合 金も $1.0 \%$ の炭素を添加した合金もほほ同じで WC 相および $\mathrm{FeAl}$ 相で構成されている. 炭素を添加した合金において, 光 学顕微鏡レベルでは遊離炭素が観察されないことから, 過剩 の炭素は FeAl 相中に固溶しているものと考えられる. そのた め, Fig3(a)の回折パターンにおいて, FeAlのピークが Fig3(b) の場合よりもシャープになっているものと考えられる.また， 炭素を添加していない合金においても $\eta$ 相に準ずるような脆 化相は生成していないものと推察される.しかし, $0.5 \%$ 炭
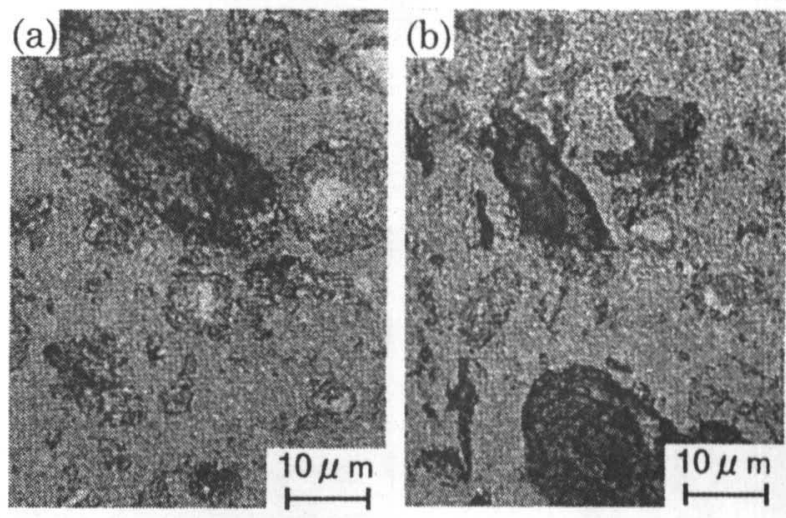

Fig.2 Microstructure of WC-10mass $\%\left(\mathrm{Fe}_{65} \mathrm{Al}_{35}\right)+0.5 \% \mathrm{C}$ and WC10 mass $\%\left(\mathrm{Fe}_{65} \mathrm{Al}_{35}\right)+1.0 \% \mathrm{C}$ alloys pulsed current sintered at $1423 \mathrm{~K}$ under $33 \mathrm{MPa}$.

(a) $0.5 \% \mathrm{C}$ addition (b) $1.0 \% \mathrm{C}$ addition

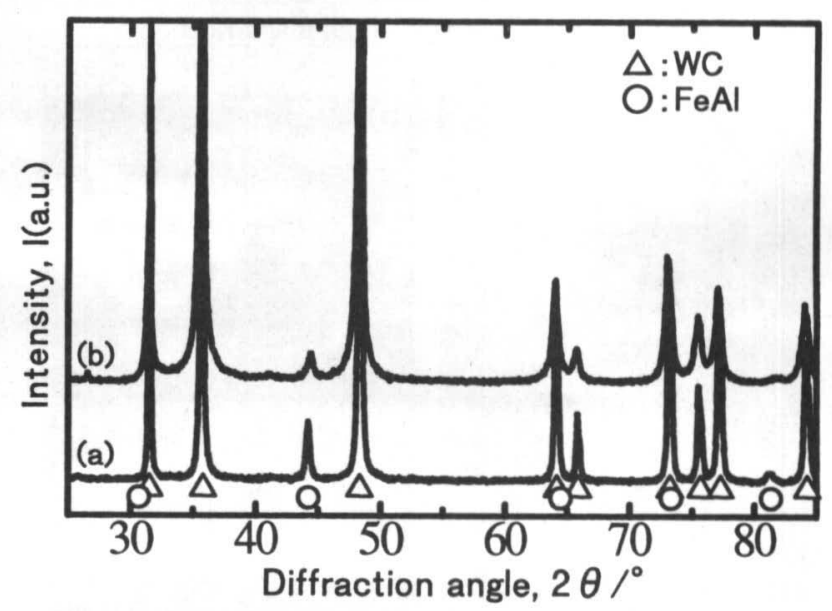

Fig.3 X-ray diffraction patterns of WC-10mass\% $\left(\mathrm{Fe}_{65} \mathrm{Al}_{35}\right)$ alloys pulsed current sintered at $1423 \mathrm{~K}$ under $33 \mathrm{MPa}$.

(a) no addition (b) $1.0 \% \mathrm{C}$ addition 
素を添加することにより, やや密度の向上が認められたこと から, 以下の実験では添加炭素量を $0.5 \%$ とすることとした. $3.2 \mathrm{WC}-10 \%\left(\mathrm{Fe}_{62.5} \mathrm{Al}_{32.5} \mathrm{~B}_{5}\right)$ 系合金の焼結評価

Fig.4 に WC-10\% $\left(\mathrm{Fe}_{62.5} \mathrm{Al}_{32.5} \mathrm{~B}_{5}\right)+0.5 \% \mathrm{C}$ 組成の合金を $1423 \mathrm{~K}$ で焼結した組織を示す. Bを添加した合金では, 添加しなかっ た合金に比べて明らかにポアが減少し, メタルプールの大き さも小さくなっている. MA合成した粉末を SEMにより観察し たところ, Fig.5に示すように $\mathrm{Fe}_{65} \mathrm{Al}_{35}$ 組成に比べて $\mathrm{Fe}_{625} \mathrm{Al}_{325} \mathrm{~B}_{5}$ 組成の粉末が微細であった. そのため, メタルプールが減少 し，焼結時に緻密化が進行したものと考えられる.WC-10\% $\left(\mathrm{Fe}_{625} \mathrm{Al}_{32.5} \mathrm{~B}_{5}\right)+0.5 \% \mathrm{C}$ 合金は密度が $13.1 \mathrm{~g} / \mathrm{cm}^{3}$ であり, B 添加 していない合金に比べて緻密化しており, その硬さも HRA92.2 と高くなっている.一方, 抗折力については $0.29 \mathrm{GPa}$ と依然として低い水準になっている．この合金におけるX線 回折パターンをFig.6に示す.Bを添加したことによる新しい 相の形成は認められず，構成相はWC-10\% $\left(\mathrm{Fe}_{65} \mathrm{Al}_{35}\right)$ 合金の場 合と同じであった.

WC-10\% $\left(\mathrm{Fe}_{625} \mathrm{Al}_{32.5} \mathrm{~B}_{5}\right)+0.5 \% \mathrm{C}$ 組成の合金を $1473 \mathrm{~K} て ゙$ 焼結し た組織を Fig.7に示す. 組織に大きな変化は認められず, その 硬さは HRA92.0であり, $1423 \mathrm{~K}$ で焼結した合金と同程度で あった.ただ, 密度は $13.5 \mathrm{~g} / \mathrm{cm}^{3}$ とわずかながら向上してお
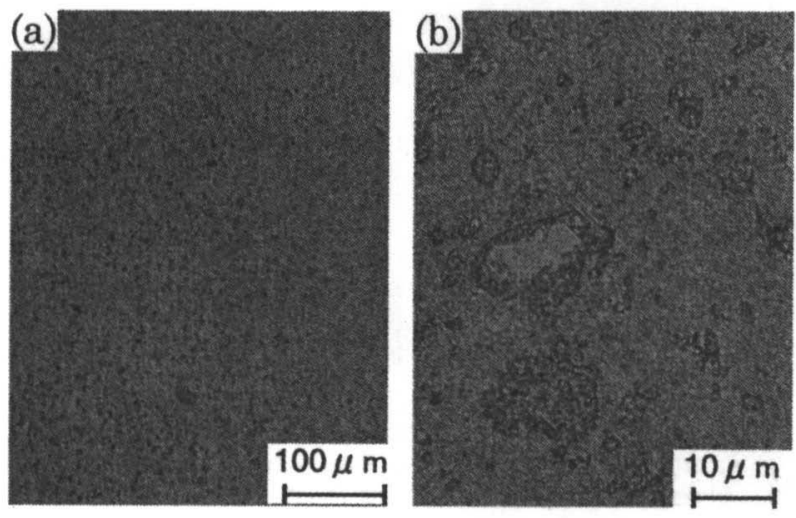

Fig.4 Microstructure of WC-10mass\% $\left(\mathrm{Fe}_{62.5} \mathrm{Al}_{32.5} \mathrm{~B}_{5}\right)+0.5 \mathrm{C} \%$ alloy pulsed current sintered at $1423 \mathrm{~K}$ under $33 \mathrm{MPa}$.

(a) low magnification (b) high magnification
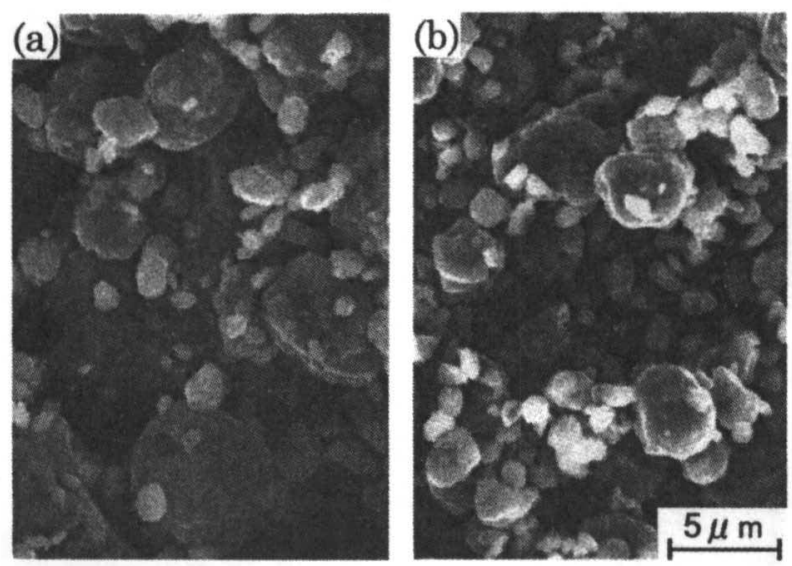

Fig.5 SEM image of $\mathrm{Fe}_{65} \mathrm{Al}_{35}$ and $\mathrm{Fe}_{625} \mathrm{Al}_{32.5} \mathrm{~B}_{5}$ powders mechanically alloyed. (a) $\mathrm{Fe}_{65} \mathrm{Al}_{35}$ (b) $\mathrm{Fe}_{625} \mathrm{Al}_{32.5} \mathrm{~B}_{5}$
その抗折力は $0.42 \mathrm{GPa}$ となった. 抗折力は低い水準であるが, 本合金の抗折力は焼結温度を高くすることにより緻密化か進 行するため改善される可能性があることがわかった.

詳細な組織観察を行うため，1423K で焼結した WC-10\% $\left(\mathrm{Fe}_{62.5} \mathrm{Al}_{32.5} \mathrm{~B}_{5}\right)+0.5 \% \mathrm{C}$ 合金について SEM/EDXによる分析を 行った.この結果を Fig.8に示す. SEM 像に示すA 部および $\mathrm{B}$ 部は $\mathrm{Fe}$ と $\mathrm{Al}$ がともに検出され, MA処理粉末の粗大な粒子 がメタルプールとして残存しているものと考えられる. A 部 のようなメタルプールで定量分析を行うと $\mathrm{Fe}$ と $\mathrm{Al}$ の比がほ ほ配合組成に一致していることがわかった．B部のメタル プールでは外周部が $\mathrm{Al}$ おび 0 の濃度が高くなっていること がわかる.このことから B 部のようなメタルプールの外周部 では $\mathrm{Al}$ の酸化物, $\mathrm{Al}$ と $\mathrm{Fe}$ の複合酸化物, もしくは酸素がリッ チな層が形成され, 合金の緻密化と抗折力の向上を阻害して いるものと推察される. おそらく, MA 処理中に MA 雾囲気 から酸素をピックアップした結果, 酸素の多い粉末が一部合 成されたものと考えられる. また，C部では炭素のみが検出 されることから遊離炭素であろうと考えられる. 添加した炭 素は焼結温度が低く, 短時間である本成形プロセスにおいて

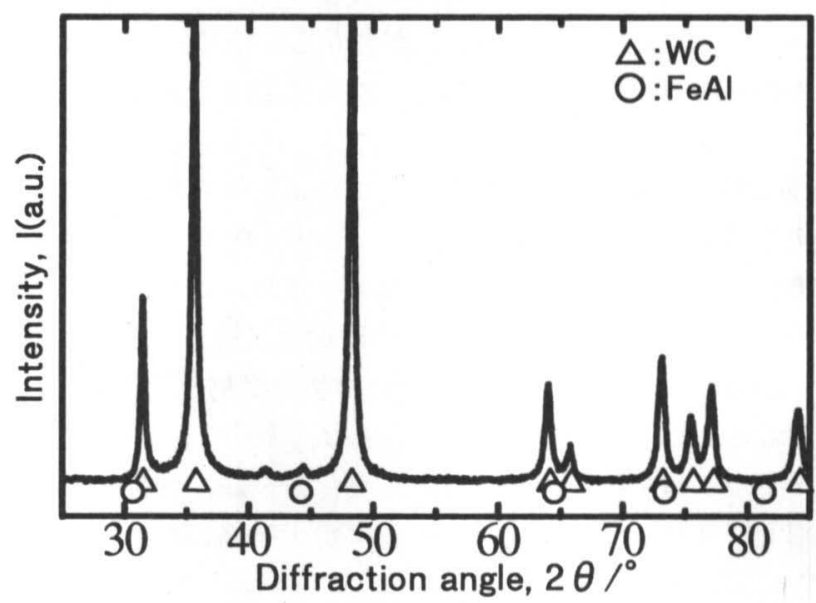

Fig.6 X-ray diffraction pattern of WC-10mass\% $\left(\mathrm{Fe}_{62.5} \mathrm{Al}_{32.5} \mathrm{~B}_{5}\right)$ alloys pulsed current sintered at $1423 \mathrm{~K}$ under $33 \mathrm{MPa}$.
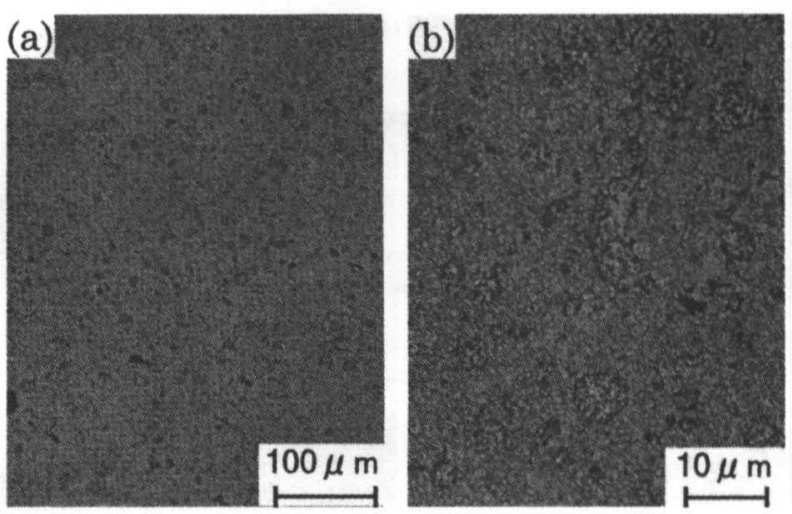

Fig.7 Microstructure of WC-10mass\% $\left(\mathrm{Fe}_{62.5} \mathrm{Al}_{32.5} \mathrm{~B}_{5}\right)+0.5 \% \mathrm{C}$ alloy pulsed current sintered at $1473 \mathrm{~K}$ under $33 \mathrm{MPa}$. (a) low magnification (b) high magnification 

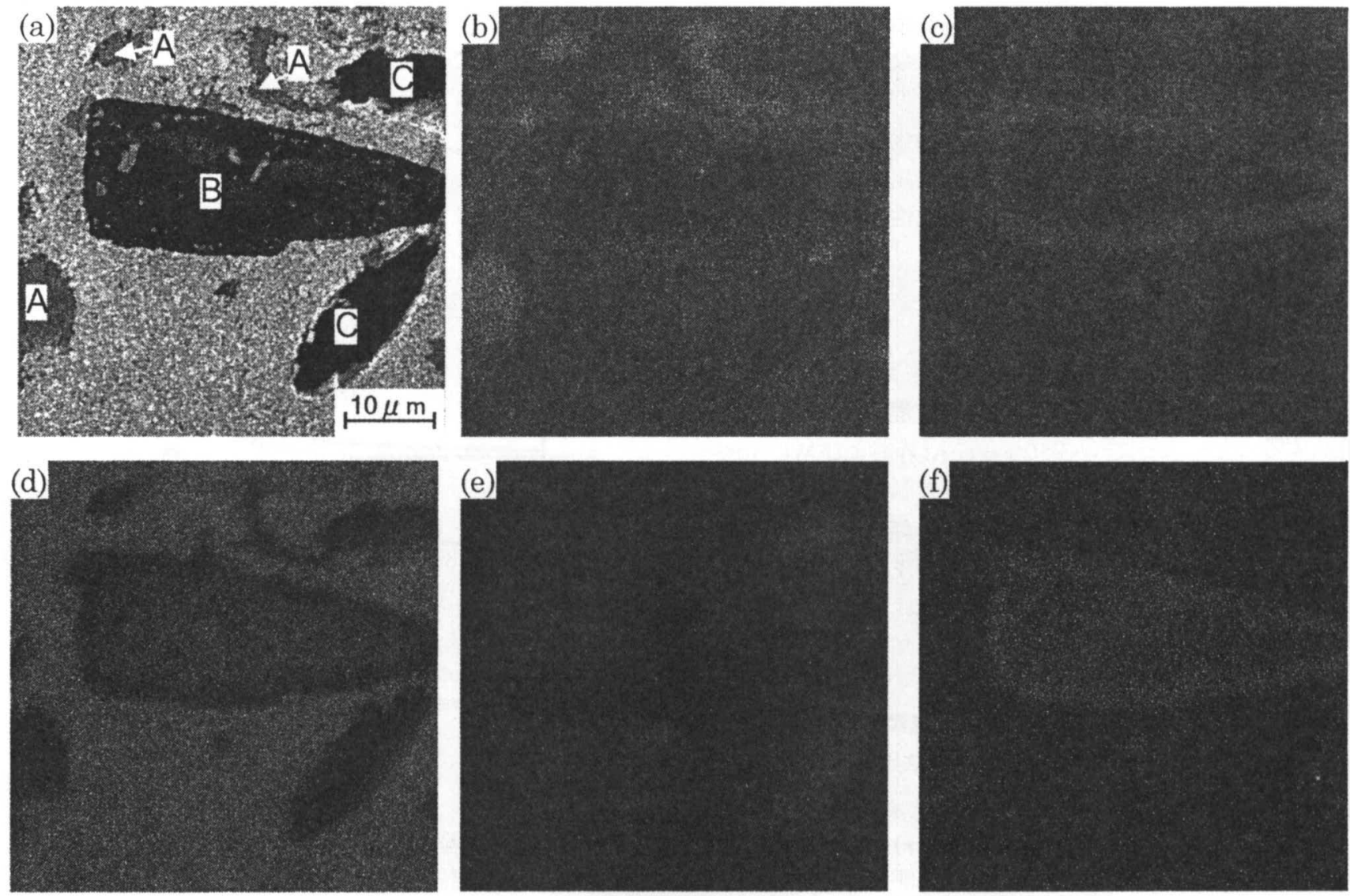

Fig.8 SEM/EDX image of WC-10mass $\%\left(\mathrm{Fe}_{62.5} \mathrm{Al}_{32.5} \mathrm{~B}_{5}\right)+0.5 \% \mathrm{C}$ alloy pulsed current sintered at $1423 \mathrm{~K}$ under $33 \mathrm{MPa}$.

(a) SEM, (b) Fe $\mathrm{K} \alpha$, (c) $\mathrm{Al} \mathrm{K} \alpha$, (d) $\mathrm{W} \mathrm{M} \alpha$, (e) $\mathrm{C} \mathrm{K} \alpha$, (f) $\mathrm{O} \mathrm{K} \alpha$

は完全に脱酸素剂としては働かず, 未反応の炭素が微細に合 金中に分散したものと考えられる.WC- $10 \%\left(\mathrm{Fe}_{65} \mathrm{Al}_{35}\right)$ 系合金 では遊離炭素が認められず, WC-10\% $\left(\mathrm{Fe}_{625} \mathrm{Al}_{32.5} \mathrm{~B}_{5}\right)$ 系合金で 遊離炭素が検出されれた理由としては, B を添加した合金系 ではCが固溶すべきサイトをBが占有するために遊離炭素が 生成したのではないかと考えられる.

\section{$3.3 \mathrm{WC}-10 \%\left(\mathrm{Fe}_{625} \mathrm{Al}_{325} \mathrm{~B}_{5}\right)$ 系合金の改善}

そこで合金を緻密化するために, MA粉末に混入する酸素 量の低減を検討した.MA粉末に混入する酸素量の低減はMA 処理の際の封入ガスであるアルゴンガスの圧力を大気圧から 67kPaとすることにより実現した. すなわち, アルゴンガス中 に含まれる微量の酸素あるいは窒素を MA 粉末がピックアッ プして容器内が減圧になっても外気を吸込まない処理を行っ た . 大気圧のアルゴンガス雾囲気中で M A 処理した $\mathrm{Fe}_{625} \mathrm{Al}_{325} \mathrm{~B}_{5}$ 粉末と減圧アルゴンガス䨌囲気中で MA処理した $\mathrm{Fe}_{625} \mathrm{Al}_{325} \mathrm{~B}_{5}$ 粉末の酸素混入量の違いを Table 1 に示す. 減圧ア ルゴンガス雾囲気中で MA 処理した粉末を W C-10\% $\left(\mathrm{Fe}_{625} \mathrm{Al}_{325} \mathrm{~B}_{5}\right)+0.5 \% \mathrm{C}$ 組成になるようWC粉末, 炭素粉末と混 合し, $1423 \mathrm{~K}$ で燒結すると, 密度は $13.2 \mathrm{~g} / \mathrm{cm}^{3}$ となり, 抗折力 については0.78GPa と2倍以上になった. なお, 得られた合金 の組織は大きな変化が認められず, 硬さはHRA91.0とやや低 下した.0.78GPaという抗折力は実用合金としてはまだ不十分
Table 1 Oxygen content of pulsed current sintered WC-10mass\% $\left(\mathrm{Fe}_{62.5} \mathrm{Al}_{32.5} \mathrm{~B}_{5}\right)+0.5 \% \mathrm{C}$ alloys.

\begin{tabular}{|l|l|}
\hline \multicolumn{2}{|c|}{ oxygen content (mass\%) } \\
\hline $\begin{array}{l}\text { before } \\
\text { the improvement }\end{array}$ & $\begin{array}{l}\text { after } \\
\text { the improvement }\end{array}$ \\
\hline 3.41 & 0.37 \\
\hline
\end{tabular}

である.この原因は依然として存在する酸素がMA処理粉末 の表面に酸化物などを生成し, 十分な焼結性を得られていな いことによると考えられる.したがって, MA処理粉末の微細 化, 結合相の分散の改善, 混入酸素量の低減, 焼結条件の適 正化を図ることにより，烊結性を改善し，抗折力を実用レベ ルまで向上させることができると考えられる.

\section{4 耐酸化性評価}

本開発合金の耐酸化特性を調べるためにWC- $10 \%\left(\mathrm{Fe}_{65} \mathrm{Al}_{35}\right)$, WC-10\% $\left(\mathrm{Fe}_{625} \mathrm{Al}_{322} \mathrm{~B}_{5}\right)$ および比較合金として微粒子系WC-Co 合金(粒成長抑制剤添加)を同一形状に加エして, 大気中にて TG測定を行った.温度に対するそれぞれの試料の重量変化を Fig.9に示す. それそれの試料の酸化開始温度は, WC-Co合金 
が $983 \mathrm{~K}$ と最も低く, WC- $10 \%\left(\mathrm{Fe}_{65} \mathrm{Al}_{35}\right)$ 合金か5 $1026 \mathrm{~K}, \mathrm{WC}-$ $10 \%\left(\mathrm{Fe}_{625} \mathrm{Al}_{325} \mathrm{~B}_{5}\right)$ 合金か' $1041 \mathrm{~K}$ と最も高くなっている. 本開 発合金が優れた耐酸化性を有していることがわかる。特に, B の添加は MA 粉末の微細化だけでなく耐酸化性の改善にも大 きく寄与することがわかった. FeAlを結合相とする超硬合金 は䌂密化させることにより，さらに耐酸化性が改善されるも のと期待される.

\section{4 ま と め}

$\mathrm{Fe}$ 粉末, $\mathrm{A} 1$ 粉末あるいは Fe粉末, $\mathrm{A} 1$ 粉末, $\mathrm{B}$ 粉末を $\mathrm{MA}$ 処 理し, 得られた MA粉末とWC粉末を湿式混合し,パルス通 電焼結することによって WC-10\% $\left(\mathrm{Fe}_{65} \mathrm{Al}_{35}\right)$ および WC-10\% $\left(\mathrm{Fe}_{625} \mathrm{Al}_{325} \mathrm{~B}_{5}\right)$ 組成の新しい超硬合金を作製した. 得られた超 硬合金の組織と機械的性質を調べ，以下の結果が得られた。

(1) $\mathrm{WC}-10 \%\left(\mathrm{Fe}_{65} \mathrm{Al}_{35}\right)$ 合金に比べ WC-10\% $\left(\mathrm{Fe}_{625} \mathrm{Al}_{325} \mathrm{~B}\right.$ ) 合金 の方が緻密化し高い硬さを示した.これは，Bの添加によ りMA粉末が微細になったことに起因しているものと考え られる。

(2) WC-10\% $\left(\mathrm{Fe}_{622} \mathrm{Al}_{325} \mathrm{~B}_{5}\right)$ 合金において, 酸素量を $0.37 \%$ に低 減した合金では, 酸素量が3.4\%の合金に比べて0.78GPa 2倍以上の抗折力を示した。

(3) $\mathrm{WC}-10 \%\left(\mathrm{Fe}_{65} \mathrm{Al}_{35}\right)$, WC-10\% $\left(\mathrm{Fe}_{625} 5 \mathrm{Al}_{325} \mathrm{~B}_{5}\right)$ および微粒子系 WC-Co 合金を大気中で加熱すると，本開発合金はいずれ もWC-Co合金よりも酸化開始温度が高く，特にWC- $10 \%$ $\left(\mathrm{Fe}_{625} \mathrm{Al}_{32,5} \mathrm{~B}_{5}\right)$ 組成の超硬合金では酸化開始温度が1041Kと 優れた耐酸化性を示した.

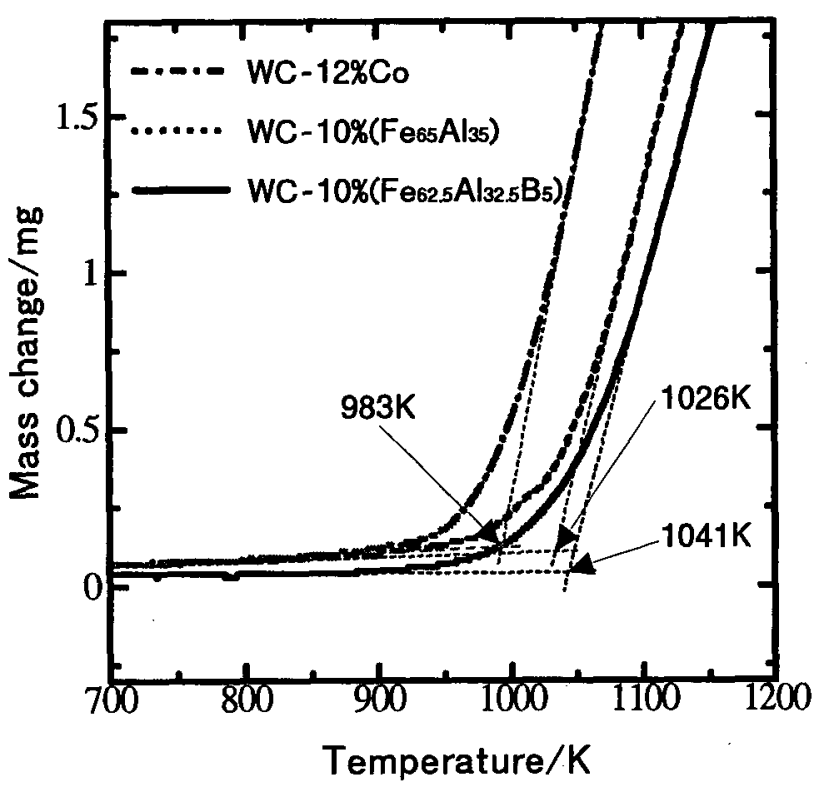

Fig.9 TG curves of WC-12mass\%Co, WC-10mass $\%\left(\mathrm{Fe}_{65} \mathrm{Al}_{35}\right)$ and $\mathrm{WC}-10$ mass\% $\left(\mathrm{Fe}_{62.5} \mathrm{Al}_{32.5} \mathrm{~B}_{5}\right)$ alloy in the air.

文献

1) 小林慶三, 三輪謙治, 福永稔, 町田正弘 : " Fe-Al 合金を結 合相にした超硬合金の作製 ", 粉体および粉末冶金, 41 (1994)14-17.

2) 福永稔, 町田正弘, 小林慶三:"結合相にアルミニウムを含む 超硬合金の焼結性",粉体および粉末冶金, 42(1995)422-426. 